M. Klimczuk-Kochańska, A. Klimczuk, Social and Solidarity Economy, [in:] M. Odekon (ed.), The SAGE Encyclopedia of World Poverty, 2nd Edition, SAGE Publications, Thousand Oaks 2015, pp. 1413-1416. https://doi.org/10.4135/9781483345727.n734

\title{
Social and Solidarity Economy
}

The social and solidarity economy concept refers to enterprises, organizations, and innovations that combine the production of goods, services, and knowledge with achieving economic and social goals as well as solidarity building.

Ideas of social economy emerged in Europe in the first half of the 19th century. In many countries, working-class people experienced a deterioration of living conditions because of the expansion of industrial capitalism. Representatives of the peasants and workers launched selfhelp groups and initiatives such as cooperatives and mutual benefit societies that were independent of the traditional philanthropy of the wealthy. Some examples of this are the Rochdale Society of Equitable Pioneers and Robert Owen in England, Raiffeisen cooperatives in Germany, Charles Fourier and Philippe Buchez in France, and Stanislaw Staszic and Wacław Bliziński in Poland.

The concept remerged in French academic discourse in the 1980s and spread to most European countries, Latin America, North America, and Asia. At the beginning of the 21st century, the social economy is considered a possibility for a "third way" of development after the collapse of state-controlled economies and the criticism of liberal economies.

\section{Social and Solidarity Economy Relations With Public, Private, and Civic Sectors}

The social and solidarity economy is not a sector of the economy but an approach to theory and practice, which includes initiatives in different sectors of the economy.

The social economy mainly includes cooperative, not-for-profit, and voluntary activities that make this concept similar to the third sector of society that includes citizen associations and foundations. The third sector is defined by reference to the public sector (state, government, public administration) and the private sector (commercial entities). The social economy differs from the third sector by including paid activities that are subordinated to social aims within communities, across national economies, and internationally.

Moreover, the social economy seeks to place informal activities from the shadow economy that are not officially measured or valued into formal, legal structures. The shadow economy consists of neighborhood help and self-help activities, family and household, and the illegal or grey economy. Formal structures are emerging for placing a value on social and economic activities that were previously not valued and often underestimated, such as help for the elderly or people with disabilities or local exchange and trading systems.

The social economy is also regarded as a part of the welfare mix, welfare pluralism, and 
M. Klimczuk-Kochańska, A. Klimczuk, Social and Solidarity Economy, [in:] M. Odekon (ed.), The SAGE Encyclopedia of World Poverty, 2nd Edition, SAGE Publications, Thousand Oaks 2015, pp. 1413-1416. https://doi.org/10.4135/9781483345727.n734

"mixed economy of welfare." These concepts promote collaboration in poverty reduction and social policy among the different public, private, citizen, and informal entities. They include hybrid organizations, initiatives such as partnerships, and resources with plural origins that can be defined as the market (sales of goods and services), nonmarket (government subsidies, donations), and nonmonetary (volunteers).

The solidarity economy is an influential variant of the social economy and is also known as the new social economy, popular economy, economy of the poor, economy of local communities, and civic economy. The term solidarity economy is primarily used in France, Latin America, and Quebec to make the distinction between "old" and "new" social economy mechanisms and organizations. It underlines the fact that some older entities (for example, banking and insurance) are already part of the mainstream capitalistic economy.

Moreover, the newer solidarity economy aims beyond social goals by fostering solidarity as an answer to injustice and to counteract the black-economy organizations that may evolve from the shadow economy (such as Mafia-like organizations or gangs). The solidarity economy includes fair trade organizations, worker cooperatives, trade unions, open-source and openaccess development, commons-based peer production, ethical purchasing organizations, and local currencies. There are also market and social innovations aimed at translating economic means into social goals, such as socially responsible investment, social investment, impact investment, the social stock market, social banking, community reinvestment funds, and microfinance.

\section{Primary Values, Principles, and Entities}

The usually recognized values of the social and solidarity economy are related to production, distribution, and consumption. These activities should be undertaken to foster democratization; citizen involvement; local, national, and global cooperation; sustainability; equality and justice; diversity; meeting human needs; co-responsibility; and co-ownership of wealth.

Principles for achieving these values are focused on providing work and welfare services for excluded and vulnerable members of the community. Thus, the rules of the "old" social economy were filling market niches unattractive to commercial enterprises, grassroots-based initiatives, autonomy, and democratic self-management, mutuality and solidarity among local and global social economy community members, self-sufficiency insofar as it is feasible, productive diversification, and sustainable management of local resources. Some of the primary entities of this old social economy were cooperatives, mutual insurance companies, and credit 
M. Klimczuk-Kochańska, A. Klimczuk, Social and Solidarity Economy, [in:] M. Odekon (ed.), The SAGE Encyclopedia of World Poverty, 2nd Edition, SAGE Publications, Thousand Oaks 2015, pp. 1413-1416. https://doi.org/10.4135/9781483345727.n734

unions.

Rules for the new social economy are still under development. Among the rules usually described are buffering or building alternatives to markets; inclusion of marginalized and "mixing risk groups," that is, the cooperation of able employees and people with disabilities; the significant role of managers; the state as establisher and promoter of initiatives; jobs for the poor that are subsidized by the state; and legal advantages for social economy entities.

Contemporary entities that are typical of the new social economy are social enterprises, social cooperatives, and nongovernment organizations with income-generating activities. Similar to these institutions are socially responsible businesses, which emerged at the end of the 20th century. However, these businesses focused on profitmaking, shareholder accountability, and profit redistribution to shareholders, while social economy entities are characterized by a social mission, stakeholder accountability, and reinvesting profits by social programs or operational costs.

\section{Social Enterprises and Poverty Reduction}

Social enterprises are often recognized as the main social economy entities by their activities in the areas of social protection, food support, agricultural production, consumer affairs, craftwork, housing, residential services, education, culture-related training, and sports and leisure activities. Their legal forms vary in different countries and continents.

However, there are attempts to build a common theory for these enterprises, for example, by the European Social Enterprise Research Network, which proposed indicators to identify them. Economic and entrepreneurial dimensions of social enterprises are continuous activity producing goods and/or selling services, significant levels of economic risk, and a minimum amount of paid work. Social dimensions include an aim to benefit the community, initiatives launched by a group of citizens or civil society organizations, and limited profit distribution. The final criteria are participatory governance of social enterprises, including a high degree of autonomy, decision-making power not based on capital ownership, and participatory nature that involves various parties affected by the activity (users or customers).

Government support for social economy entities is recognized in the European Union, Brazil, and Argentina. In the countries of Africa and Asia, support for the social economy comes from citizen forums and networks on sustainable development and the United Nations' agencies. Among policy themes on social enterprises are improving access to financial resources, research for increasing understanding and visibility, capacity building, and access to 
M. Klimczuk-Kochańska, A. Klimczuk, Social and Solidarity Economy, [in:] M. Odekon (ed.), The SAGE Encyclopedia of World Poverty, 2nd Edition, SAGE Publications, Thousand Oaks 2015, pp. 1413-1416. https://doi.org/10.4135/9781483345727.n734

public procurement.

Magdalena Klimczuk-Kochańska

Stanislaw Staszic College of Public Administration

Andrzej Klimczuk

Warsaw School of Economics

See Also: Civic Society; Community Development and Poverty Reduction; Rural Development and Poverty Reduction; Social Exclusion; Social Movements.

\section{Further Readings}

Allard, Jenna, Carl Davidson, and Julie Matthaei, eds. Solidarity Economy: Building Alternatives for People and Planet: Papers and Reports From the U.S. Social Forum 2007. Chicago: ChangeMaker, 2008.

Alter, Kim. Social Enterprise Typology. Washington, DC: Virtue Ventures, 2006.

Amin, Ash, ed. The Social Economy: International Perspectives on Economic Solidarity. New York: Zed Books, 2009.

Birkholzer, Karl, et al. Local Social Economy Learning Package: A European Curriculum for Social Enterprise Practitioners and Supporters. Berlin: Technologie-Netzwerk, 2009.

Defourny, Jacques, Patrick Develtere, and Benedicte Fonteneau, eds. Social Economy: North and South. Leuven, Belgium: Katholieke Universiteit Leuven, 2000.

Defourny, Jacques, and Marthe Nyssens. "The EMES Approach of Social Enterprise in a Comparative Perspective.” EMES European Research Network, Working Paper 12/03, 2012.

Di Meglio, Roberto, Coumba Diop, and Martin Gasser. Social and Solidarity Economy: Our Common Road Towards Decent Work. Turin, Italy: International Training Centre of the ILO, 2011.

Rymsza, Marek, ed. Social Economy, Nonprofit Sector and Social Policy: Poland and Europe. Trzeci Sektor Special Edition. Warsaw: IPS, 2008. 